\title{
På sviktende kunnskapsgrunnlag? Assistert befruktning for lesbiske par
}

\author{
Sigrun Saur Stiklestad
}

Artikkelen drøfter i hvilken grad den norske loven om assistert befruktning for lesbiske par vektlegger forskningsbasert kunnskap om barnas oppvekstvilkår. En kunnskapsteoretisk diskusjon om forholdet mellom forskning og politikk er sentral i denne drøftingen. Artikkelens empiriske grunnlag er i hovedsak dokumenter om lovprosessen, resultater fra forskningsfeltet generelt og tilsvarende lovprosess i Sverige. Dessuten drøftes kritikken rettet mot forskningsfeltet. Artikkelen viser at forskningsbasert kunnskap er gitt så lav prioritet i det norske lovarbeidet at det har skapt tvil om kunnskapsstatus på området. Samtidig synliggjør artikkelen at det foreligger mer forskning på aktuelle forskningsfelt, som samlet sett går i favør av assistert befruktning for lesbiske par.

Nøkkelord: assistert befruktning, lesbiske mødre, forskningsstatus, betydningen av farsfravær

\section{Innledning}

Etter innføringen i Norge av felles ekteskapslov for heterofile og homofile par 1. januar 2009 kan to personer av samme kjønn inngå ekteskap på lik linje med to av motsatt kjønn. Som en følge av lovendringen kan også ektepar av samme kjønn bli vurdert som adoptivforeldre. Det mest sentrale i denne sammenheng er at den nye loven gir lesbiske par, som er gift eller samboere i ekteskapslignende forhold, tilgang til assistert befruktning. Tidligere sa samfunnet nei til lesbiske par på vegne av de ufødte barna. Lovendringen kan leses som at samfunnet har endret oppfatning. Siden det norske helsevesenet i all hovedsak er offentlig finansiert, er det som i samfunnets øyne anses moralsk akseptabelt, ofte sammenfallende med det tillatte. Det 
gjør Norge forskjellig fra eksempelvis USA, hvor det meste tillates, men hvor den moralske beslutningen er individualisert.

Målsettingen med denne artikkelen er å se nærmere på hvordan barneperspektivet er blitt integrert i lovarbeidet som omhandler lesbiske pars adgang til assistert befruktning. I den forbindelse er det av spesiell interesse å se hvordan forskningsbasert kunnskap om barn som vokser opp med likekjønnede foreldre, er blitt vektlagt. Et sentralt anliggende i så måte er å foreta en kunnskapsteoretisk diskusjon om sammenhengen mellom forskning og politikk. Det empiriske grunnlaget for denne artikkelen er i hovedsak offentlige dokumenter som omhandler lovprosessen. Videre ser vi på forskningen som er lagt til grunn for loven, i lys av forskningsfeltet om barn med samkjønnede foreldre. I artikkelen trekkes det paralleller til tilsvarende lovprosess i Sverige, og denne sammenligningen gir utdypende perspektiv på vektleggingen av forskningen av barnas situasjon i den norske prosessen. Avslutningsvis retter vi oppmerksomheten mot kritikken som er blitt reist mot forskningsfeltet, mer spesifikt hvorvidt forskningen på feltet taler med tilstrekkelig sikkerhet for å kunne si noe om mulige konsekvenser av å vokse opp uten en far.

\section{Lovbestemmelsen}

Assistert befruktning reguleres i Norge i lov om humanmedisinsk bruk av bioteknologi m.m. (bioteknologiloven). I $\$ 2-1$ i denne loven defineres assistert befruktning som henholdsvis inseminasjon og befruktning utenfor kroppen. Inseminasjon defineres som innføring av ektemannens sæd eller donorsæd i kvinnen på annen måte enn ved samleie. Videre defineres befruktning utenfor kroppen som befruktning av egg utenfor kvinnens kropp. Assistert befruktning som begrep brukes i tillegg som en samlebenevnelse for alle behandlingsformene. I denne artikkelen benyttes begrepet kun i betydningen inseminasjon av donorsæd. Det har sammenheng med at et tilbud om assistert befruktning for lesbiske kvinner først og fremst innebærer inseminasjon av donorsæd, selv om befruktning utenfor kroppen unntaksvis også kan være aktuelt dersom det skulle bli påvist medisinsk infertilitet hos kvinnen. ${ }^{1}$

\section{Veien fra kriminalisering til assistert befruktning}

For å forstå rekkevidden av at lesbiske kvinner nå tilbys assistert befruktning i Norge, kan det være nyttig med et tilbakeblikk over nær norsk historie. I løpet av de siste årtiene har det skjedd en formidabel holdningsendring i favør av lesbiske kvinner og homofile menn (se f.eks. Ulstein Moseng, 
Hegna \& Kristiansen 1999). Forbudet i straffeloven mot sex mellom menn ble opphevet i 1972, ti år senere ble homofili som sykdomsdiagnose fjernet, og med partnerskapsloven i 1993 ble lesbiske og homofile tilkjent juridiske rettigheter. Sammenlignet med ekteskapsloven var partnerskapsloven unntatt mulighet til adopsjon og vigsel. Til tross for unntaket om adopsjon, bidro debatten om innføringen av partnerskapsloven til at adopsjon for lesbiske og homofile partnere ble satt på dagsordenen. I denne sammenheng kan det også være verdt å merke seg at manglende kunnskap om barnas oppvekstvilkår ble brukt som argument mot adopsjon (Ot.prp. nr. 32, 1992-1993).

Neste milepæl var i 2002 da registrerte partnere fikk adgang til stebarnsadopsjon. Nettopp fordi manglende kunnskap om barns oppvekstvilkår tidligere ble vektlagt som argument mot adopsjon, er det grunn til å forvente at denne lovendringen bygde på samme argumentasjon, men da med motsatt fortegn. Det var ikke tilfelle, i stedet var kunnskap om barnas situasjon helt utelatt i forarbeidet til loven (Ot.prp. nr. 71, 2001-2002).

Startskuddet for felles ekteskapslovgivning var dokument 8 -forslaget om kjønnsnøytral ekteskapslovgivning i 2004, fra stortingsrepresentantene Siri Hall Arnøy (SV) og May Hansen (SV) (Dokument nr. 8:52, 2003-2004). ${ }^{2}$ Adopsjonsprøverett for lesbiske og homofile var en del av dette forslaget, men til forskjell fra den nå vedtatte loven, var rett til assistert befruktning for lesbiske par fraværende i denne omgang. Forslaget hadde ikke politisk flertall, men innstillingskomiteen anmodet Stortinget om å be Regjeringen utrede spørsmålet nærmere (Innst. O. nr. 9, 2004-2005). Forslaget medførte at adopsjonsdebatten blusset opp på ny i media. En viktig grunn til det var at Barneombudet gikk imot at lesbiske og homofile skulle gis lik rett til å bli vurdert som adoptivforeldre som heterofile (TV2-nyhetene 2004). En viktig bestanddel i Barneombudets argumentasjon var påstanden at det ikke forelå forskning på adopsjon til homofile par, og at man av den grunn visste lite hva adopsjon ville medføre for det enkelte barn (Hjermann 2004, jf. Barneombudet 2004). Det var et synspunkt som møtte delvis sterk motbør, anført av profilerte homofile aktører (Krekling 2004; Juritzen 2004).

Kunstig befruktning for lesbiske kvinner, som det da het, ble første gang tematisert i stortingsmeldingen Evaluering av lov om medisinsk bruk av bioteknologi (St.meld. nr. 14, 2001-2002). Saken ble diskutert i forbindelse med vilkår for tilbud om kunstig befruktning, nærmere bestemt hvem som bør få tilbud om behandling. Etter diskusjonen i meldingen å dømme, hadde spørsmålet blitt aktualisert av innføringen av stebarnsadopsjon tidligere samme år. Det ble også vist til diskusjoner i Danmark om lesbiske par burde få tilbud om kunstig befruktning, som i 1998 førte til at det ble reist lovforslag om en slik endring. Dette forslaget ble for øvrig forkastet av det danske Folketinget. Foruten å bringe innføringen av stebarnsadopsjon og diskusjonene i Danmark på bane, avstedkom ikke temaet noen større diskusjon i 
meldingen. Snarere ble et tilbud for lesbiske kvinner raskt avvist som mulighet under henvisning til den medisinske begrunnelsen at kunstig befruktning var et tilbud for å avhjelpe mannlig og kvinnelig medisinsk infertilitet, og at årsaken til barnløshet for lesbiske kvinner var en annen enn den gjeldende lovs begrunnelse.

Med innstillingen fra sosialkomiteen om bioteknologiloven i 2003 ble begrepet kunstig befruktning erstattet med assistert befruktning (Innst. O. nr. 16, 2003-2004). I innstillingen ble betingelsen om medisinsk infertilitet igjen diskutert, men fastholdt. Likevel kan man merke seg at det var en bevegelse i diskusjonen ved at kunnskapsgrunnlaget omkring barns oppvekstforhold ble gjort til et tema. Det ble til og med fremlagt forslag, riktignok av et mindretall, om en offentlig utredning om barn som vokser opp med lesbiske og homofile foreldre. Det ble blant annet vist til at Sverige hadde fått en bred debatt på grunnlag av den offentlige utredningen Barn $i$ homosexuella familier (SOU 2001:10). En norsk utredning ble det imidlertid ikke noe av.

Det endelige forslaget om assistert befruktning for lesbiske par ble forelagt av Barne- og likestillingsdepartementet i Høringsnotat forslag om felles ekteskapslov for likekjønnede og ulikekjønnede par i 2007 (Barne- og likestillingsdepartementet 2007). En viktig markør i så måte var at flertallet i Bioteknologinemnda gikk inn for assistert befruktning for lesbiske par (Bioteknologinemnda 2007, jf. Barne- og likestillingsdepartementet 2007).

\section{Argumentasjonen for lovforslaget}

Barne- og likestillingsdepartementets overordnede argument for lovforslaget var at assistert befruktning for lesbiske par ville medføre likebehandling, og dermed likestilling mellom lesbiske og heterofile par. I tillegg ble det argumentert ut fra et rettighetsperspektiv når det gjaldt barna. Argumentasjonen var at barn med lesbiske mødre og født ved hjelp av donor, skulle likebehandles med barn med heterofile foreldre tilkommet på samme måte. Departementet refererte i den anledning til at ved fastsettelse av foreldreskap for medmor har lesbiske mødre til nå måttet gå veien via stebarnsadopsjon. Det ble påpekt at det er en praksis som står i kontrast til fastsettelse av farskap. Heterofile par som har fått barn på nøyaktig samme måte, har i stedet fått saken behandlet etter barneloven. Det innebærer at det har vært tilstrekkelig at mors ektemann eller samboer har samtykket til behandlingen for at han kan erklæres som barnets far etter dom. I høringsnotatet ble det foreslått tilsvarende regel for fastsettelse av foreldreskap for mors kvinnelige ektemake, med den nye juridiske betegnelsen; fastsettelse av medmorskap. Det anføres fra departementets side at medmorskapet kan være på plass fra barnet blir født. Da unngår en usikkerheten som har vært 
knyttet til den skjønnsmessige vurderingen som ligger til grunn for stebarnsadopsjon, og barnet sikres juridisk dersom biologisk mor dør under eller like etter fødselen (Barne- og likestillingsdepartementet 2007). I den påfølgende odelstingsproposisjonen, Felles ekteskapslov for heterofile og homofile par (Ot. prp. nr. 33, 2007-2008), argumenterte Barne- og likestillingsdepartementet i tillegg for at det er positivt for barna at lesbiske par får assistert befruktning i Norge, for det innebærer at barna får rett til informasjon om sædgivers identitet etter at de har fylt 18 år.

\section{Tvist om forskning på barnas oppvekstvilkår}

I høringsnotatet fra Barne- og likestillingsdepartementet (BLD) ble det også fremhevet at barnas oppvekstvilkår er et viktig moment i saken. I den forbindelse ble det forut for høringsnotatet gjennomført en litteraturgjennomgang om barn som vokser opp med likekjønnede foreldre (Barne- og likestillingsdepartementet 2007). Etter oppdrag fra Barne- og likestillingsdepartementet ble litteraturgjennomgangen gjennomført av kriminolog Katharina Gjeruldsen. Av mandatet for oppdraget fremgår det at hovedvekten av kunnskapsoversikten bør konsentrere seg om norske og nordiske undersøkelser, men et resymé av nyere amerikanske undersøkelser kan også være av interesse. Innledningsvis fremgår det at utreder synes det er viktig å presisere at hun ikke har arbeidet med homofilispørsmål tidligere. Videre poengterer hun at tiden har vært en stor utfordring ved at hun har hatt to måneder til disposisjon for sitt arbeid. Litteraturgjennomgangen er på til sammen 36 sider (Gjeruldsen 2006).

I litteraturgjennomgangen vises det til den svenske utredningen Barn $i$ homosexuella familjer (SOU 2001:10), og til Fiona L. Tasker og Susan Golombok (1997) sin longitudinelle undersøkelse Growing up in a lesbian family, hvor barn først ble intervjuet i 10-årsalderen og igjen 15 år senere. Av forskning i Norge vises det til at det først og fremst er hovedfagsstudenter som har forsket på dette temaet. Konklusjonen av litteraturgjennomgangen gjengis her i sin helhet, og er som følger:

Gjennom den foretatte kunnskapsoversikten er det ikke funnet studier som avdekker særlige avvik mellom heterofile og homofile par verken når det gjelder parets oppfatning av foreldrerollen eller barnets oppvekstvilkår. Det fremgår bl.a. at den biologiske morens kvinnelige partner (sosial mor), oppleves som en viktig person $\mathrm{i}$ barnets liv og bidrar aktivt til oppfostring og oppdragelse av barnet. Det fremkommer heller ingen forskjell når det gjelder barnas evne til å få eller beholde venner, deres psykiske og sosiale velbefinnende eller deres kjønnsutvikling. (Barne- og likestillingsdepartementet 2007: pkt. 5.3.5) 
I allerede refererte svarbrev fra Bioteknologinemnda til BLD er forskningen på feltet gjenstand for diskusjon, en diskusjon som også er gjengitt $\mathrm{i}$ høringsnotatet. Hovedpunktene er hvorvidt forskningen på feltet er tilstrekkelig for å kunne si noe om mulige konsekvenser for barn som vokser opp uten en far. Bioteknologinemnda refererer til at en rekke forskere på feltet hevder at forskningen entydig kan oppsummeres med at barn ikke tar noen påviselig skade av farsfraværet. Samtidig viser nemnda til at andre forskere har satt spørsmålstegn ved kvaliteten på forskningen, som innbefatter kritikk av at en del av undersøkelsene har få deltakere og mangler relevante kontrollgrupper. Videre refererer de til at sistnevnte forskere også har trukket frem forskning som viser at farsfravær har stor negativ betydning. Samtidig gjøres det rede for at dette er forskningsresultater som blir avvist av førstnevnte forskergruppe på grunnlag av at disse studiene omhandler det å miste en far, og ikke i tilfeller hvor man fødes til verden med to mødre og uten en far. Avslutningsvis gjør Bioteknologinemnda rede for at noen, underforstått mindretallet i nemnda, anser forskningen å være mangelfull, mens andre anser den å være tilfredsstillende (Bioteknologinemnda 2007, jf. Barne- og likestillingsdepartementet 2007).

I ovennevnte odelstingsproposisjon er høringsinstansenes syn på å tilby assistert befruktning for lesbiske par gjengitt, og i alt 57 høringsinstanser uttalte seg om forslaget (Ot.prp. nr. 33, 2007-2008). 31 av instansene var mot forslaget, og i proposisjonen presiseres det at tre av disse ikke tilhører Den norske kirke, andre trossamfunn eller kirkelige organisasjoner. En av hovedinnvendingene fra høringsinstansene som er imot lovforslaget, er at konsekvensene for barn som vokser opp med likekjønnede foreldre, må utredes nærmere. Barne- og likestillingsdepartementet innleder sitt tilsvar på kritikken med å klargjøre at de har merket seg at det er forskjellige syn på barneperspektivet. I den forbindelse vises det til at både tilhengere og motstandere begrunner sitt syn med barnets beste. Hva gjelder kunnskap om barnas situasjon eksplisitt, støtter departementet seg til resultatet av litteraturgjennomgangen. I tillegg støtter de seg til Barneombudets høringsuttalelse som fremholder at forskningen viser at ingen har funnet tegn til at barn tar skade, verken psykisk eller sosialt, av å vokse opp med likekjønnede foreldre. Departementet konkluderer med at det ikke er behov for mer forskning for å tilrettelegge for ekteskap mellom samkjønnede par. Det anføres videre at det viktigste for barn er å vokse opp i trygge og gode omgivelser, og at ekteskap er den mest stabile rammen rundt barns liv. For øvrig avholder departementet seg fra å kommentere forskningen ytterligere under punktet som omhandler assistert befruktning direkte. 


\section{Spenning helt til slutt}

I behandlingen av lovforslaget om felles ekteskapslov for heterofile og homofile par i Odelstinget var det uttrykte formålet - like rettigheter for lesbiske/homofile personer som for heterofile - sterkt fremme. Det ble blant annet trukket paralleller til innføringen av allmenn stemmerett og likestillingsloven. Som en del av samme resonnement ble det slått fast at innføringen av felles ekteskapslov ville fjerne all diskriminering av homofile og lesbiske i lovverket. Også barnas rettigheter ble fremhevet. I tillegg til argumentasjonen om å sikre barn to juridiske foreldre allerede fra fødselen av, ble det i Odelstinget sterkere betonet enn tidligere at et tilbud i Norge ville medføre at barna kunne få kjennskap til sitt mannlige biologiske opphav (Møte i Odelstinget 11. juni 2008: eks. stortingsrepresentant Gunn Karin Gjul, Ap (Ordfører for saken)).

I odelstingsdebatten oppsto det et skille i argumentasjonen. Representanter fra regjeringspartiene, samt Høyre og Venstre, som talte for lovforslaget, argumenterte i hovedsak ut fra et rettighetsperspektiv. Som en del av dette resonnementet ble det fremhevet at fraværet av like rettigheter i gjeldende lovgivning var diskriminerende. Representanter fra Kristelig Folkeparti og Fremskrittspartiet, som var imot lovforslaget, argumenterte mot at dette handlet om diskriminering. I stedet var hovedinnholdet i argumentasjonen deres at felles ekteskapslov ville medføre en svekkelse av ekteskapet som institusjon, og at barna ved innføring av assistert befruktning for lesbiske kvinner ville bli fratatt en far. Det er interessant å merke seg at det $\mathrm{i}$ hovedsak var motstanderne av lovforslaget som bygde sin argumentasjon på forskning om barnas situasjon. Blant annet ble følgende sagt i debatten, av stortingsrepresentant Ulf Erik Knudsen (FrP):

Vi bør erkjenne at erfaringen og forskningen omkring barn i homofile forhold er så mangelfull at man bør handle ut fra føre-var-prinsippet. I et dyptgripende spørsmål av denne art er det uansvarlig å innføre irreversible lovendringer når vi har så lite kunnskap. (Møte i Odelstinget 11. juni 2008: stortingsrepresentant Ulf Erik Knudsen, FrP)

I debatten gikk statsråd Anniken Huitfeldt i rette med kritikken ved blant annet å vise til at Sverige, «som har utredet saken enda mer, altså har innført assistert befruktning for lesbiske» (Møte i Odelstinget 11. juni 2008: statsråd Anniken Huitfeldt, Ap). Stortingsrepresentant Anette Trettebergstuen (Ap) tilbakeviste også behovet om mer utredning, men da ved å avvise at dette er en sak som behøver utredning overhodet, og å argumentere for at «man trenger ikke noen utredning for å slå fast at homofile og lesbiske er like gode - eller like dårlige, for den saks skyld - omsorgspersoner som det heterofile er» (Møte i Odelstinget 11. juni 2008: stortingsrepresentant Anette Trettebergstuen, Ap). Stortingsrepresentantens tilbakevisning av behovet for utredning overhodet står $\mathrm{i}$ et motsetningsforhold til statsrådens uttalelse 
om «nok utredning». Dersom man ser denne motsetningen blant meningsfeller i lys av kravet om nærmere utredning fra de som var imot lovforslaget, kan det sees som uttrykk for at forskningen på området er blitt svært politisert.

\section{Forskningens rolle for lovutviklingen i Sverige}

I Sverige har kvinner som er samboer eller partner med en annen kvinne, fått utført assistert befruktning ved svenske universitetssykehus siden 1. juli 2005 (Regeringskansliet 2005). Inntil denne lovendringen hadde denne type behandling - som i Norge, vært forbeholdt kvinner som er gift eller samboer med en mann. Et sentralt poeng i denne sammenheng er at til forskjell fra det medisinske argumentet - å avhjelpe mannlig og kvinnelig medisinsk infertilitet - som blir anvendt i Norge, har argumentasjonen i Sverige handlet om forskning. Mer presist, den opprinnelige inseminasjonsloven fra 1984 omfattet ikke lesbiske kvinner fordi man på det tidspunktet påpekte at det forelå for lite forskningsbasert kunnskap om barns situasjon unnfanget gjennom inseminasjon. Dette hevdet man i sin tur talte mot at man anvendte teknikken $i$ andre tilfeller enn for barn som kunne vokse opp med foreldre av begge kjønn (Regeringens proposition 1984/1985:2). Spørsmålet om assistert befruktning for lesbiske kvinner ble igjen aktualisert med innføringen av partnerskapsloven i 1994. Begrunnelsen for fortsatt utelatelse omhandlet også denne gang manglende forskning (Bet.1993/ 94:LU28).

I likhet med i Norge, ble adopsjon et unntak i den svenske partnerskapsloven. Likeledes bidro unntaket til å aktualisere spørsmålet om adopsjon. På dette punktet skiller situasjonen i Sverige seg fra den i Norge. I Sverige resulterte spørsmålet om adopsjon i at den svenske regjeringen i 1999 initierte en utredning og opprettet den parlamentarisk sammensatte komiteen «Barn i homosexuella familjer». Komiteen hadde to hovedoppgaver: å utrede tilgjengelig forskning om barns oppvekstvilkår og å ta stilling til de juridiske forskjellene mellom homofile/lesbiske respektive heterofile par (Regeringskansliet 2004). Dette arbeidet resulterte i utredningen Barn $i$ homosexuella familier (SOU 2001:10). ${ }^{3}$ Utredningen baser seg på i overkant av 40 undersøkelser, og de internasjonale studiene er stort sett utført i USA, men også i Storbritannia og Belgia. I tillegg ble det utført kompletterende studier ved to svenske universitet om hvordan barn som lever i lesbiske og homofile familier, selv opplever sin situasjon. Komiteen gjennomførte også en undersøkelse i samarbeid med Statistiska centralbyrån om lesbiske og homofilt foreldreskap, og om lesbiske og homofiles innstilling til familie og barn. I tillegg ble det gjennomført en undersøkelse om allmennhetens innstilling til lesbisk og homofilt foreldreskap. Med tanke på spørsmålet om 
adopsjon redegjorde også komiteen for forskning om adoptivbarns særskilte behov (Regeringens proposition 2001/2002:123). Samlet sett består utredningsarbeidet av om lag 1000 sider. Til sammenligning var den norske litteraturgjennomgangen på 36 sider.

I komiteens konklusjon anføres det at kunnskapen om barn med lesbiske og homofile foreldre fra andre land har relevans for svenske forhold. Det vises også til at forskningsmetodene som er benyttet i de utenlandske studiene, er i samsvar med metodene som brukes i psykologisk forskning om barn i Sverige. Komiteen fremhever også at resultatene av de egne kompletterende studiene er i samsvar med de internasjonale studiene (SOU 2001:10). Komiteen oppsummerer forskningsresultatene på følgende måte:

Den samlade forskningen visar att barn med homosexuella föräldrar har utvecklats psykologiskt och socialt på liknande sätt som de barn de jämförts med. Inga skillnader har heller framkommit vad gäller barnens könsutveckling. För en del av barnen kan det i vissa skeenden av uppväxten uppstå konflikter som är relaterade till föräldrarnas homosexualitet. De barn som växer upp i familjer där det finns starka positiva känslomässiga band mellan barnen och föräldrarna har dock goda förutsättningar att hantera sådana konflikter. Även om resultaten från den samlade forskningen inte fullt ut är generaliserbara kan kommittén således konstatera att vi numera har en god kunskapsbild vad avser förhållandena för barn som växer upp i homosexuella familjer. I forskningen har inga skillnader upptäckts mellan homosexuella och heterosexuella föräldrar vad gäller deras förmåga att erbjuda barn god omsorg och omvårdnad. (SOU 2001:10, pkt. 13.2.7: 306)

Utredningen av tilgjengelig forskning om barns oppvekstvilkår resulterte først i innføringen av adopsjonsprøverett for registrerte partnere på lik linje med heterofile par, også partneres rett til å adoptere hverandres barn, tilsvarende norsk stebarnsadopsjon, i 2003 (Regeringskansliet 2003). Med bakgrunn i utredningen kom regjeringen frem til at det er grunn til å anta at lesbiske par generelt sett kan tilby barn et godt oppvekstmiljø og tilgodese de særskilte behovene for omsorg som barn unnfanget ved assistert befruktning kan ha (Regeringens proposition 2004/2005:137). Det resulterte i innføringen av assistert befruktning for lesbiske kvinner i Sverige i 2005.

\section{Betydningen av farsfravær}

Kritikken rettet mot forskningen dreier seg om betydningen av farsfravær for barn med lesbiske mødre, unnfanget ved assistert befruktning. Kritikken fulgte hele lovprosessen i Norge. Denne kritikken består av to ulike bestanddeler. Den ene er påstanden om at forskningen er mangelfull, og den andre er at forskningen mangler troverdighet. I det følgende vil jeg se nærmere på denne kritikken. 
Fordi kritikken har bidratt til å skape tvil om hvorvidt man kan feste lit til forskningen, vil jeg innlede med å si noe om hvordan den empiriske dokumentasjonen er fremkommet. Et viktig moment i så måte er at Susan Golombok er en sentral kilde i denne gjennomgangen, når det refereres til både empiriske enkeltundersøkelser og oppsummerende undersøkelser. Bakgrunnen for det er at Golombok er den mest anerkjente forskeren på temaet barns utvikling i lesbiske familier. Hun står blant annet bak klassikeren Growing up in a lesbian family (Tasker \& Golombok 1997), og hennes posisjon bekreftes av en av de fremste kritikerne på forskningsfeltet, for denne studien er trukket frem som en av de mest stringente undersøkelsene på feltet (Nock 2000).

I det videre vil jeg presentere forskningsresultater om betydningen av farsfravær. Fiona MacCallum og Susan Golombok har i artikkelen «Children raised in fatherless families from infancy: A follow-up of children of lesbian and single heterosexual mothers at early adolescence» (2004) oppsummert resultatene fra forskning om dette temaet, som jeg her vil støtte meg til. De første undersøkelsene om betydningen av farsfravær konkluderte med at barn med enslige mødre hadde økt risiko for kognitive, sosiale og emosjonelle problemer (Biller 1974; Herzog \& Sudia 1973, etter MacCallum \& Golombok 2004). Forklaringen som ble lagt til grunn, var at det skyldtes farsfraværet i seg selv. Dersom man ser nærmere på familieforholdene, viser det seg at denne første forskningen var konsentrert om familier der far hadde flyttet fra familiehjemmet etter separasjon eller skilsmisse. Det innebar at barna hadde blitt eksponert både for disharmoniske foreldrerelasjoner, og for tapet av en tilstedeværende far. Andre studier som kontrollerte for de sosiale og emosjonelle problemene, tilbakeviste at det var farsfraværet i seg selv som hadde negativ innvirkning på barnas intellektuelle eller sosioemosjonelle tilpasning (Broman, Nichols, \& Kennedy 1975; Crockett, Eggebeen \& Hawkins 1993; Ferri 1976, etter MacCallum \& Golombok 2004). I stedet viste forhold som dårligere familieøkonomi seg å være den mest fremtredende faktoren knyttet til barnas vanskeligheter i eneforsørgerfamilier (McLanaLanahan \& Sandefur 1994, etter MacCallum og Golombok 2004). Et annet moment av betydning var at disse barna var blitt eksponert for konflikter mellom foreldrene. I forbindelse med foreldrenes skilsmisse erfarte barna at det nettopp var konfliktene mellom foreldrene som var den største følelsesmessige belastningen (Amato 1993, etter MacCallum \& Golombok 2004). At farsfravær i seg selv ikke nødvendigvis er et problem, bekreftes av funn som viser at barn som aldri har bodd med sine fedre, ikke oppviser samme problemer (Ferri 1976, etter Golombok 2000). Barns vansker knyttet til farsfravær er altså mer sammensatt enn hva man kan få inntrykk av når farsfravær forklares i termen av uteblivelse av mannlig rollemodell (MacCallum \& Golombok 2004). 
Den videre gjennomgangen av forskning om betydningen av farsfravær omhandler eksplisitt barn med lesbiske mødre. En sentral kilde i denne sammenheng er artikkelen «Children of lesbian mothers: From the 1970s to the Millennium» (Mooney-Somers \& Golombok 2000). De første studiene på barn med lesbiske mødre ble igangsatt i Storbritannia og USA mot slutten av 1970-tallet. Foranledningen til forskningen var at flere lesbiske mødre skilte seg, og at deres seksuelle orientering ble gjenstand for vurdering i barnefordelingssaker. Det innebar antakelsen om, og ikke minst bekymringen for, at barn som vokser opp med lesbiske mødre er i risikosonen for å utvikle psykiske problemer og atypisk kjønnsutvikling. Bekymringen for barnas utvikling var basert på den allment aksepterte oppfatningen at noen erfaringer i barndommen medfører risiko for ens psykiske helse. I dette tilfellet hadde det sammenheng med at homofili ikke var sosialt akseptert, og at man av den grunn antok at barna ville bli utsatt for sosial fordømmelse. Man antok at barna ville bli ertet og mobbet av sine jevnaldringer, noe man hevdet kunne resultere $\mathrm{i}$ at de ble sosialt mistilpasset. I tillegg ble det antatt at de ikke kunne få eller beholde venner, noe som igjen ville medføre dårligere selvtillit og ha negativ innvirkning på deres psykologiske helse senere i livet.

Den første sentrale undersøkelsen om barn med fraskilte lesbiske mødre ble påbegynt i Storbritannia i slutten av 1970-tallet, for å undersøke om det var noe hold i antakelsene nevnt ovenfor. Undersøkelsen var en komparativ studie av barn i skolealder, henholdsvis med frakilte lesbiske mødre og enslige heterofile mødre. Bakgrunnen for å sammenligne disse utvalgene var å se hvilken betydning farsfravær og mødrenes seksuelle orientering hadde for barnas utvikling. Studien viste at barna med lesbiske mødre verken ble ertet eller mobbet mer eller opplevde psykiske vanskeligheter i større grad enn barna med heterofile mødre (Golombok, Spencer \& Rutter 1983, etter Mooney-Somers \& Golombok 2000).

I samme tidsperiode ble det utført flere undersøkelser i USA på barn med fraskilte lesbiske mødre. Den første undersøkelsen var Green (1978). Den ble etterfulgt av kontrollstudier publisert av Green, Mandel, Hotvedt, Gray og Smith (1986) og Kirkpatrick, Smith og Roy (1981). MooneySomers og Golombok påpeker i sin artikkel at resultatene fra disse studiene var påfallende like resultatene fra Storbritannia: Det å vokse opp med lesbiske mødre var ikke til skade for barnas sosiale eller emosjonelle utvikling.

For å kontrollere for mulige langtidseffekter av å vokse opp i lesbiske familier ble barna i studien fra Storbritannia fulgt opp 14 år senere. Den longitudinelle studien motsvarer den allerede omtalte klassikeren på området: Growing up in a lesbian family (Tasker \& Golombok 1997). ${ }^{4}$ I den longitudinelle studien kombineres kvantitative og kvalitative metoder. Originalstudien baserer seg i hovedsak på standardiserte intervju, og i oppfølgingsstudien kombineres standardiserte og semi-strukturerte intervju. I den 
første undersøkelsen ble to grupper sammenlignet, bestående av 27 lesbiske mødre og deres 39 barn, og tilsvarende antall single, heterofile mødre og deres barn. Barna var i gjennomsnitt 9.5 år. Da oppfølgingsstudien ble utført 14 år senere, var barnas gjennomsnittsalder altså 23,5 år. 18 av de 27 lesbiske mødrene fra den originale gruppen, og 25 av deres barn, og 16 av de single heterofile mødrene og 21 av deres barn deltok i oppfølgingsstudien.

Hovedfunnene fra den longitudinelle studien er at barna i lesbiske familier fortsatt hadde god mental helse da oppfølgingsstudien ble utført. Likeledes viste studien at kvaliteten på familierelasjonene, nærmere bestemt forholdet til mor, mors partner og far, var gode. Det samme gjaldt deres relasjoner til venner og partnere. Med tanke på utvikling av barnas seksuelle orientering viste studien at 23 av 25 av de unge voksne med lesbiske mødre identifiserte seg som heterofile. Det var ingen forskjell mellom gruppene når det gjaldt rapportering av minst et tilfelle av tiltrekning til noen av samme kjønn. Derimot viste undersøkelsen at flere med lesbiske mødre hadde overveid muligheten for å ha forhold til noen av samme kjønn (Tasker \& Golombok 1997). Det innebærer at de i mindre grad tar sin seksuelle orientering for gitt.

I motsetning til innledende undersøkelser om barn med fraskilte lesbiske mødre har senere studier omhandlet barn som fra starten av har vokst opp i lesbiske familier, i betydningen at barna er født av kvinner som har definert seg som lesbiske før de ble mødre. Mange av disse barna er unnfanget ved donorinseminasjon. Den første studien av dette slag ble utført i USA i 1985 (Steckel 1985; 1987, etter Mooney-Somers \& Golombok 2000). Undersøkelsen viste at barn med lesbiske mødre og heterofile mødre var mer like, enn forskjellige. Etterfølgende studier, også fra USA, viste sammenlignbare resultater: Samtlige 37 barn i alderen 4-9 år i Pattersons (1994) studie utviste atferd som var innenfor normalområdet. Det samme gjorde barna i undersøkelsen til Flaks, Ficher, Masterpasqua \& Joseph (1995), som ikke fant noen forskjell i atferdsmessig tilpasning eller kognitiv fungering $i$ sammenligningen av 15 lesbiske familier og 15 heterofile familier. Videre viste Chan, Raboy \& Pattersons (1998) undersøkelse av 55 lesbiske familier at foreldrenes seksuelle orientering var irrelevant, ikke bare for barnas atferdsmessige tilpasning, men også for deres sosiale kompetanse.

I Storbritannia sammenlignet Golombok \& Tasker (1994) 30 barn i alderen 3-8 år, som fra fødselen av hadde vokst opp med lesbiske mødre, og hvor de fleste av barna var unnfanget ved donorinseminasjon, med et matchet utvalg bestående av 42 familier med single heterofile mødre og 41 familier med to heterofile foreldre med barn unnfanget ved donorinseminasjon. Barna i de lesbiske familiene viste seg å være like psykisk veltilpass, og ikke mer disponert for emosjonelle vansker eller atferdsproblemer enn barna fra de to andre familietypene. Det ble heller ikke funnet noen forskjell 
mellom de ulike gruppene med tanke på hvor godt barna følte seg akseptert av sine mødre og jevnaldringer, selv om barna i familiene med fravær av far i noe mindre grad følte seg trygg på sine fysiske og kognitive ferdigheter. I Belgia kom Brewaeys, Ponjaert, Van Hall \& Golombok (1997) frem til tilsvarende resultater i sammenligningen av 30 lesbiske familier med barn unnfanget ved donorinseminasjon og 68 heterofile familier med to foreldre. Med bakgrunn i resultatene presentert over konkluderer Mooney-Somers og Golombok (2000) med at det å vokse opp med lesbiske mødre fra fødselen av, ikke er noen tilleggsrisiko for barns psykologiske utvikling.

Den første undersøkelsen basert på et stort nasjonalt utvalg, ble utført i USA i 2004 (Wainright et al. 2004). I studien sammenlignes ungdommer i alderen 12-18 år som har lesbiske mødre, med ungdommer i tilsvarende alder som har heterofile foreldre. De lesbiske mødrene i studien ble identifisert ved at foreldrene rapporterte å være gift med eller leve i ekteskapslignende forhold med en person av samme kjønn. Av studien fremgår det ikke hvorvidt barna er resultat av tidligere heterofile forhold eller om de er født inn i planlagte lesbiske familier. Tidligere studier har imidlertid sannsynliggjort at majoriteten foreldre i planlagte lesbiske familier har fått utført donorinseminasjon (Gartrell et al. 1999; Rothizen et al. 2001, etter Bos \& Hakvoort 2007), og det gir grunn til å tro at også utvalget i Wainright et al. innbefatter barn med lesbiske mødre unnfanget ved donorinseminasjon. Resultatene fra undersøkelsen viste at foreldrenes seksuelle orientering var uten betydning for hvor godt ungdommene klarte seg på det personlige plan. Det ble ikke funnet noen forskjeller mellom gruppene når det gjaldt selvtillit, depressive symptomer eller angst. Det ble heller ikke påvist noen forskjeller på hvor godt ungdommene gjorde det på skolen, det vil si hvilke karakterer de fikk, samt deres følelse av tilhørighet på skolen og atferd. Undersøkelsen viste derimot at det var en klar sammenheng mellom hvordan ungdommen fungerte og kvaliteten på deres relasjon til foreldrene sine. Ungdommer som hadde et godt forhold til foreldrene, klarte seg best på nevnte områder (Wainright et al. 2004).

\section{Sviktende kunnskapsgrunnlag?}

Som tidligere diskutert i artikkelen har kritikken mot forskningsfeltet bidratt til å trekke kunnskapsstatusen i tvil. Når man ser nærmere på kritikken, er det viktig å ha i mente at dette er et svært politisert forskningsfelt, og at kritikken av forskningen delvis må forstås ut fra en slik sammenheng. For å sette nevnte kritikk i perspektiv vil jeg først presentere det jeg anser være hovedlinjene fra forskningsfeltet.

Uansett forskningsfelt må samtlige undersøkelser som publiseres i vitenskapelige tidsskrifter, gjennom en omfattende vitenskapelig kontroll, i 
form av fagfellevurdering. Metode, teoribruk og holdbarheten i resultatene er sentrale momenter i denne vurderingen. Studier om barn med lesbiske mødre er intet unntak fra denne regelen. De fleste undersøkelser som omhandler barnas utvikling, har brukt dybdeobservasjoner foretatt av flere sentrale observatører som foreldre, lærere, klinikere og forskere, og standardiserte tester. Målsettingen med studiene har vært å forstå komplekse og nyanserte problemstillinger knyttet til barns psykologiske utvikling under påvirkning av ulike former for foreldreskap og intervensjon fra voksne. Dette forskningsdesignet er i tråd med generelt aksepterte vitenskapelige standarder for psykologi som forskningsdisiplin. Flere av artiklene er publisert i de mest prestisjefylte internasjonale tidsskriftene innenfor feltet barns utvikling, som tidsskriftene Child Development og Developmental Psycho$\log y$ (Stacey \& Biblarz 2001).

Å trekke i tvil hvorvidt kunnskapsgrunnlaget er tilstrekkelig for å kunne si noe om mulige konsekvenser av at barn vokser opp uten far, er ikke av ny dato. Steven L. Nock er en av de fremste representantene som hevder at den metodologiske tilnærmingen i studiene, og følgelige kvaliteten på forskningen, ikke holder nødvendig akademisk standard. Nocks hovedbidrag i denne sammenheng er gjennomgang av 49 fagfellevurderte studier i tidsrommet 1978 til 2000. Hans konklusjon er at samtlige artikler inneholder minst én alvorlig feil, og at ikke en eneste artikkel er utført i henhold til generell akseptert vitenskapelig standard. Det innebærer at alle studiene praktisk talt hevdes å være uvitenskapelige, og således uten verdi. Nock fremholder at man ganske enkelt ikke vet hvordan det går med barn med lesbiske og homofile foreldre, sammenlignet med barn med heterofile foreldre (Nock 2000). Det betyr at samtlige 49 artikler, som etter vitenskapsverdenens egen bedømming er blitt vurdert som vitenskapelige, har Nock bedømt som uvitenskapelige.

Undersøkelsene det rettes kritikk mot, er i hovedsak psykologiske studier. Nock går følgelig i rette med forskningsdesignet som er vurdert å holde vitenskapelig mål innenfor psykologisk forskning. Han anvender sitt eget utgangspunkt som survey-forsker og befolkningsstatistiker som vitenskapelig målestokk. Av den grunn fremstår undersøkelser som benytter andre vitenskapelige metoder, som de han her kritiserer, som uvitenskapelige. Fra denne posisjonen gjør han seg til talsmann for at spørreundersøkelser basert på representative nasjonale utvalg er den eneste akseptable forskningsmetoden innenfor samfunnsforskning generelt. Han hevder videre at man ikke kan feste lit til forskningsresultatene spesielt fordi ingen av studiene han referer til, er basert på nasjonale utvalg, men på bekvemmelighetsutvalg som er for små til å kunne etablere statistiske forskjeller mellom grupper. Videre hevder han at utvalgene ikke er representative, og at funnene ikke kan generaliseres for å kunne sammenligne foreldre av samme kjønn med heterofile foreldre (Nock 2000). Forskningsundersøkelsene 
innenfor psykologifaget oppfyller følgelig ikke Nocks vitenskapelige standard.

Den omtalte klassikeren Growing up in a lesbian family er ifølge Nock et eksempel på en undersøkelse som ikke holder nødvendig vitenskapelig standard. Han anerkjenner undersøkelsen som en av de mest stringente innenfor dette forskningsfeltet, men avviser forskningsresultatene fordi det etter hans oppfatning ikke ble utført nødvendig statistisk kontroll for å kompensere for ytre faktorer. Når det gjelder barnas kjønnsidentitet og seksuell orientering, hevder Nock at det ikke er grunnlag for å hevde at det ikke er noen forskjell mellom barn med lesbiske mødre og barn med heterofile mødre. Denne påstanden begrunnes med funn fra undersøkelsen som viser at det er større sannsynlighet for at barn med lesbiske mødre har erfaring med likekjønnede forhold enn unge voksne med heterofile mødre (Nock 2000). Judith Stacey og Timothy Biblarz (2001) har gjennomgått Nocks kritikk, og konkluderer med at dersom man skulle akseptere professor Nocks bedømmelse av disse studiene, måtte man i praksis avvise hele faget psykologi som forskningsdisiplin. Å kaste vrak på så å si hele forskningsfeltet ved å hevde at resultatene ikke sier noe om disse barnas situasjon, slik Nock gjør, fremstår med bakgrunn i dette som noe ytterliggående.

Det er for øvrig et poeng at man ved bruk av utvalg som ikke er representative, ikke kan foreta statistiske generaliseringer til populasjonen. Konsekvensen av det er at man på grunnlag av denne type utvalg ikke kan slå fast at funnene fra aktuelle undersøkelser også gjelder for befolkningen som helhet. Det er derfor ideelt sett ønskelig med et større representativt utvalg, for å kunne si noe om både omfang og årsakssammenhenger. I mangel på sådanne, vil imidlertid en analyse av de studiene som er gjennomført, gi det beste resultat for å si noe samlet om situasjonen til barn som vokser opp med lesbiske mødre.

\section{Avsluttende kommentar}

Denne artikkelen viser at Barne- og likestillingsdepartementet i all hovedsak argumenterte for assistert befruktning for lesbiske par ut fra et rettighetsperspektiv, med full rettslig likestilling mellom heterofile og lesbiske/ homofile par og deres barn som det uttalte mål. Artikkelen viser at dette står i et motsetningsforhold til tilsvarende lovprosess i Sverige, hvor empirisk forskning om barnas situasjon utgjorde selve kjernen i argumentasjonen.

Artikkelen synliggjør at manglende kunnskap om barnas oppvekstvilkår ble brukt som argument mot adopsjon allerede i forbindelse med partnerskapsloven, men også senere, da debatten om adopsjon blusset opp igjen i 2004. Sannsynligheten var derfor stor, ikke bare for at det skulle bli et sentralt anliggende også i denne debatten, men at det i tillegg ville oppstå strid 
om temaet. Denne striden gjorde det etter min oppfatning umulig å reindyrke rettighetsperspektivet, tvert imot bidro det til å skjerpe kravet til myndighetene om å presentere aktuelle forskning på en overbevisende måte.

Som vist ble det også laget en litteraturgjennomgang om barn som vokser opp med likekjønnede foreldre i Norge, men hverken litteraturgjennomgangen eller forarbeidene for øvrig tok høyde for å gripe tak i kritikken rettet mot forskningsfeltet. I stedet ble litteraturgjennomgangen stående side om side med Bioteknologinemndas diskusjon om hvorvidt forskningen på feltet var tilstrekkelig for å si noe om betydningen av farsfravær for barn med lesbiske mødre unnfanget ved assistert befruktning. Paradoksalt nok bidro litteraturgjennomgangen på denne måten til å skape tvil om kunnskapsstatus på området. Dette inntrykket forsterkes dersom man sammenholder kunnskapsstatusen i Norge med Sverige. På grunnlag av utredningen konstaterte den svenske komiteen at de hadde et godt kunnskapsbilde av forholdene for barn som vokser opp med samkjønnede foreldre. Fordi Sverige satset langt mer på utredning enn Norge, er det grunn til å tro at de av den grunn unngikk tilsvarende diskusjoner i det svenske lovarbeidet. Det resulterte $\mathrm{i}$ at forskningsresultatene som forelå $\mathrm{i}$ Sverige, fremsto som langt mer robuste og tilforlatelige enn i Norge.

Fordi assistert befruktning for lesbiske par var den delen av lovgivningen det var knyttet størst usikkerhet til i Norge, var det etter mitt skjønn et politisk sjansespill ikke å utnytte potensialet som ligger i argumentasjon basert på kunnskap. Det viktigste i denne sammenheng er imidlertid det at forskningsbasert kunnskap om barnas oppvekstvilkår fikk så lav prioritet at det bidro til å tilsløre kunnskapsstatus på området. Det skapte et mulighetsrom for motstanderne av loven til å trekke inn vitenskapen, i håp om å kunne si at det ikke var til barnas beste å vokse opp med lesbiske foreldre - samtidig som politikerne som var for loven, ikke støttet seg til forskning som dokumenterer at det går bra med barna. Motstanderne kunne på denne måten dra veksler på usikkerheten dette skapte, og bruke den som grunnlag for sin tvil og sitt nei til loven, som av samme grunn ble stående ubesvart av forkjemperne for loven. Disse forholdene tatt $\mathrm{i}$ betraktning er min påstand at assistert befruktning for lesbiske par i Norge ble innført på sviktende kunnskapsgrunnlag. Som denne artikkelen har vist, er ikke det på grunn av at det ikke foreligger dokumentert kunnskap på området, heller tvert imot. Forklaringen ligger heller i at myndighetene ikke har gjort tilstrekkelig for å presentere foreliggende kunnskap på en grundig, og dertil overbevisende måte.

Barnets beste er implementert i norsk lov og utgjør et fundament $\mathrm{i}$ barneretten. Begrepet har ikke et entydig innhold, og er i mange sammenhenger å betrakte som en overordnet grunnverdi hvor faglig skjønn er påkrevd, og som defineres ulikt avhengig av profesjon og kontekst (Barneog familiedepartementet \& Utenriksdepartementet 2003). Hovedlinjene i 
begrepet er at barns interesser og behov skal vektes foran voksnes når rettslige spørsmål skal avgjøres. Hva som er barnets behov, stilles åpent, slik at innholdet skal kunne utvikle seg i takt med skiftende verdioppfatninger i samfunnet, tilpasset til enhver tid gjeldende oppfatning om hva som er best for barnet (Haugli 2003).

Bioteknologinemnda har tradisjon for å vurdere assistert befruktning ut fra hensynet til barnets beste. For å finne ut hva barnets beste er i denne sammenheng, er det nærliggende å søke i forskningsbasert kunnskap om barn som allerede lever i denne typen familiekonstellasjon. Som forskningsresultatene viser, er sannsynligheten stor for at det vil gå bra med disse barna. Spørsmålet er dersom forskningsresultatene skulle ha indikert at det ikke gikk så bra med dem, ville da rettighetsargumentet fremdeles ha blitt tillagt avgjørende betydning? Etter min oppfatning bør alltid hensynet til barnets beste veie tyngst. Dersom forskningen hadde gått i disfavør av barna, hadde det vært uetisk å tilby assistert befruktning til lesbiske par. Det er imidlertid ikke situasjonen, da forskningen samlet sett peker i positiv retning for assistert befruktning for lesbiske par.

\section{Noter}

1 Befruktning utenfor kroppen er mest kjent som prøverørsbehandling, men blir også kalt IVF (in vitro fertilisering).

2 Et dokument 8-forslag er stortingsrepresentantenes mulighet til å fremme private saker i Stortinget, på linje med proposisjoner og meldinger fra regjeringen.

3 SOU (Statens offentliga utredningar) tilsvarer vår NOU (Norges offentlige utredninger).

4 For å gi et noe mer utførlig bilde av den longitudinelle studien er det her lagt til opplysninger om i originalstudien.

\section{Litteratur}

Amato, P. (1993) Children's adjustment to divorce:Theories, hypotheses, and empirical support. Journal of Marriage and the Family, 55, s. 23-38.

Barne- og likestillingsdepartementet. (2007). Høringsnotat forslag om felles ekteskapslov for likekjønnede og ulikekjønnede par, 16. mai 2007. Oslo: Forfatteren.

Barne- og familiedepartementet \& Utenriksdepartementet. (2003) Barnets rettigheter. Norges tredje rapport til FNs komité for barnets rettigheter. Oslo. Barne- og familiedepartementet. Utenriksdepartementet.

Barneombudet. (2004) Om adopsjon til homofile par. Ikke homofob, men barnevennlig. Lastet ned 17. februar 2009 fra www.barneombudet.no/kommentar_/ 2004/om_adopsj_/ 
Besl. O. nr. 91 (2007-2008) Lov om endringer i ekteskapsloven, barnelova, adopsjonsloven, bioteknologiloven $\mathrm{mv}$. (felles ekteskapslov for heterofile og homofile par). Oslo: Odelstinget.

Bet. 1993/94:LU28. Lagutskottets betänkanden. Registrerat partnerskap m.m. Stockholm: Justitiedepartementet.

Biller, H. B. (1974) Paternal deprivation: Family, school, sexuality, and society. Lexington, MA: Lexington Books.

Bioteknologinemnda (2006) Saddonasjon til lesbiske og enslige? Rapport 30. mars 2007. Oslo: Forfatteren.

Bioteknologinemnda (2007) Endring av bioteknologiloven for å tillate assistert befruktning til lesbiske par. Svarbrev til Helse- og omsorgsdepartementet, 1. februar 2007. Oslo: Forfatteren.

Bos, H. M. W. \& Hakvoort, E. M. (2007) Child adjustment and parenting in planned lesbian families with known and as-yet unknown donors. Journal of Psychosomatic Obsterics and Gynecology, 28 (2), s. 121-129

Brewaeys, A., Ponjaert, I., Van Hall, E. V. \& Golombok, S. (1997) Donor insemination: Child development and family functioning in lesbian mother families. Human Reproduction, 12, s. 1349-1359.

Broman, S. H., Nichols, P. L. \& Kennedy, W. A. (1975) Pre-school IQ: Parental and early development correlates. Hillsdale, NJ: Erlbaum.

Chan, R.W., Raboy, B. \& Patterson, C. J. (1998) Psychological adjustment among children conceived via donor insemination by lesbian and heterosexual mother, Child Development, 69, s. 443-457.

Crockett, L. J., Eggebeen, D. J., \& Hawkins, A. J. (1993) Fathers' presence and young children's behavioral and cognitive adjustment. Journal of Family Issues, 14, s. $355-377$.

Dokument nr. 8:52 (2003-2004) Privat forslag fra stortingsrepresentantene Siri Hall Arnøy og May Hansen. Oslo: Representanter.

Ferri, E. (1976) Growing up in a one parent family. Slough: NFER.

Flaks, D. K., Ficher, I., Masterpasqua, F. \& Joseph, G. (1995) Lesbians choosing motherhood: A comparative study of lesbian and heterosexual parents and their children. Developmental Psychology, 31, s. 105-114.

Gartrell, N., Deck, A., Rodas, C., Preyser, H. \& Banks, A. (1999) The national lesbian family study, 2. Interviews with mothers of toddlers. American Journal of Orthopsychiatry, 69, s. 362-369.

Gjeruldsen, K. (2006). Barn som vokser opp i likekjønnspar. Oslo: Barne- og likestillingsdepartementet.

Golombok, S., Spencer, A. \& Rutter, M. (1983) Children in lesbian and single parent households:Psychosexual and psychiatric appraisal, Journal of Child Psychology and Psychiatry, 24, s. 551-572.

Golombok, S. \& Tasker, F. (1994). Children in lesbian and gay families: Theories and evidence, Annual Review of Sex Research, 5, s. 73-100.

Golombok, S. (2000) Parenting: What really counts? London: Routledge.

Green, R. (1978) Sexual identity of 37 children raised by homosexual or transsexual parents. American Journal of Psychiatry, 135 (6), s. 692-697.

Green, R., Mandel, J. B., Hotvedt, M. E., Gray, J. \& Smith, L. (1986) Lesbian mothers and their children: A comparison with solo parent heterosexual mothers and their children. Archives of SexualBehaviour, 15, s. 167-184. 
Haugli, T. (red.) (2003) Nordisk samarbeid og utfordringer knyttet til innholdet $i$ begrepet barnets beste. Rapport fra ekspertmøte i Tromsø 29.-31. januar 2003 på oppdrag fra Barne- og familiedepartementet og Nordisk Ministerråd. Skriftserie nr. 56. Tromsø: Det Juridiske fakultet, Universitet i Tromsø.

Herzog, E. \& Sudia, C. (1973) Children in fatherless families. I Review of child development research, red. B. Caldwell \& H. Ricciuti, vol. 3, s. 141-232. Chicago, IL: University of Chicago Press.

Hjermann, R. (2004) Ikke homofob, men barnevennlig. VG, 26. juli 2004.

Innst. O. nr. 9 (2004-2005) Innstilling fra familie-, kultur- og administrasjonskomiteen om forslag fra stortingsrepresentantene Siri Hall Arnøy og May Hansen om lov om endring i lov 4. Juli $1991 \mathrm{nr} 47$ om ekteskap. (kjønnsnøytral ekteskapslov). Oslo: Familie-, kultur- og administrasjonskomiteen.

Innst. O. nr. 16 (2003-2004) Innstilling fra sosialkomiteen om lov om humanmedisinsk bruk av bioteknologi m.m. (bioteknologiloven). Oslo: Sosialkomiteen.

Juritzen, A. (2004) Barnefiendtlig barneombud. VG, 24. juli 2004.

Kirkpatrick, M., Smith, C. \& Roy, R. (1981) Lesbian mothers and their children: A comparative survey, American Journal of Orthopsychiatry, 51, s. 545-551.

Krekling, D. V. (2004) Lesbe refser barneombudet. Dagbladet, 22. juli 2004.

Lov om humanmedisinsk bruk av bioteknologi m.m. (bioteknologiloven). LOV-200312-05-100. Oslo: Helse- og omsorgsdepartementet.

MacCallum, F. \& Golombok, S. (2004) Children raised in fatherless families from infancy: A follow-up of children of lesbian and single heterosexual mothers at early adolescence. Journal of Child Psychology and Psychiatry, 45 (8), s. 14071419.

McLanahan, S. \& Sandefur, G. (1994) Growing up with a single parent: What hurts, what helps. Cambridge, MA: Harvard University Press.

Mooney-Somers, J. \& Golombok, S. (2000) Leading comment. Children of lesbian mothers: from the 1970s to the new Millennium. Sexual \& Relationship Therapy, 15 (2), s. 121-126.

Møte i Odelstinget onsdag 11. juni 2008. Sak nr. 1. Innst. O. nr. 63 (20072008) Innstilling fra familie- og kulturkomiteen om lov om endringer av ekteskapsloven, barnelova, adopsjonsloven, bioteknologiloven mv. (felles ekteskapslov for heterofile og homofile par), jf. Ot.prp. nr. 33 (2007-2008). Debattinnlegg: stortingsrepresentant Gunn Karin Gjul, Ap (Ordfører for saken); stortingsrepresentant Ulf Erik Knudsen, FrP; statsråd Anniken Huitfeldt, Ap; stortingsrepresentant Anette Trettebergstuen, Ap.

Nock, S. L. (2000) Affidavit of Steven Lowell Nock. Ontario. Superiour Court Of Justice (Divisional Court). Court File No. 684/00. Canada.

Ot.prp. nr. 32 (1992-1993) Registrert partnerskap. Oslo: Barne- og familiedepartementet.

Ot.prp. nr. 71 (2000-2001) Om lov om endringer i lov 28. februar 1986 nr. 8 om adopsjon og i lov 30. april $1993 \mathrm{nr} .40$ om registrert partnerskap. Oslo: Barne- og familiedepartementet.

Ot.prp. nr. 33 (2007-2008) Om lov om endringer i ekteskapsloven, barnelova, adopsjonsloven, bioteknologiloven $\mathrm{mv}$. (felles ekteskapslov for heterofile og homofile par). Oslo: Barne- og likestillingsdepartementet.

Patterson, C. J. (1994) Children of the lesbian baby boom: Behavioural adjustment, self-concepts, and sex-role identity. I Comtemporary perspectives on lesbian and 
gay psychology: Theory, research and application, red. B. Greene \& G. Herek, s. 156-175. Beverly Hills, CA: Sage.

Regeringens proposition (1984/1985:2) Om artificiella inseminationer. Stockholm: Justitiedepartementet.

Regeringens proposition (2001/2002:123) Partnerskap och adoption. Stockholm: Justitiedepartementet.

Regeringens proposition (2004/2005:137) Assisterad befruktning och föräldraskap. Stockholm: Justitiedepartementet.

Regeringskansliet. (2003) Partnerskap och adoption m.m. Faktablad, mars 2003. Stockholm: Justitiedepartementet.

Regeringskansliet. (2004) Ny lagstiftning om partnerskap och adoption - ett exempel ur verkligheten. Lagstiftningsprocessen. Publisert 20. april 2004. Stockholm: Justitiedepartementet.

Regeringskansliet. (2005) Assisterad befruktning och föräldraskap. Faktablad, juni 2005. Stockholm: Justitiedepartementet.

Rothuizen J. (2001) Lesbisch ouderschap [Lesbian parenting]. I Liever vrouen. Theorie en praktijjk van de lesbische hulpverlening [Preferably women. Theory and practiceof lesbian specific counselling], red. K. A. P. de Bruin \& M. Balkema, s. 119-136. Amsterdam: Schorer Boeken.

SOU (2001:10) Barn i homosexuella familjer. Stockholm: Justitiedepartementet.

Stacey, J. \& Biblarz, T. (2001) Affidavit of Judith Stacey and Timothy Biblarz. Ontario. Superiour Court Of Justice (Divisional Court). Court File No. 684/00. Canada.

Steckel, A. (1985) Separation-individuation in children of lesbian and heterosexual couples. Upublisert doktorgradsavhandling, Wright Institute Graduate School, Berkley, CA.

Steckel, A. (1987) Psychosocial development of children of lesbian mothers. I Gay and lesbian parents, red. F.W. Bozett, s. 75-85. New York: Praeger.

St.meld. nr. 14 (2001-2002) Evaluering av lov om medisinsk bruk av bioteknologi. Oslo: Helse- og omsorgsdepartementet.

St.meld. nr. 29 (2002-2003) Om familien - forpliktende samliv og foreldreskap. Oslo: Barne- og likestillingsdepartementet.

Tasker, F. L. \& Golombok, S. (1997) Growing up in a lesbian family. Effects on child development. New York: The Guilford Press.

TV2-nyhetene (2004, 20. juli) Barneombudet: Advarer mot homoadopsjon.

Ulstein Moseng, B., Hegna, K. \& Kristiansen, H. W. (1999) Levekår og livskvalitet blant lesbiske kvinner og homofile menn. NOVA Rapport 1/1999. Oslo: Norsk institutt for forskning om oppvekst, velferd og aldring.

Wainright, J. L., Russell, S. T. \& Patterson, C. J. (2004). Psychosocial adjustment, school outcomes, and romantic relationships of adolescents with same-sex parents. Child Development, 75 (6), s. 1886-1898. 